\title{
Adapting the Directive SEVESO III in the Slovak Enterprises and Identifying Problem Areas during the Years 2013 - 2017
}

\author{
Katarina Holla ${ }^{1, *}$ \\ ${ }^{1}$ University of Zilina, Faculty of Security Engineering, Univerzitna 1, 010 26, Zilina, Slovakia
}

\begin{abstract}
The major industrial accidents threatening the citizens develop especially in the largest strategic chemical companies in the whole EU. The rise of such an event affects not only the people but also the environment and causes big financial losses and very often deteriorates the company's reputation. The article reflects the changes in the area of preventing major industrial accidents during last 5 years in dependence how they are perceived by the companies. The basic threshold was the year 2013 when the new directive SEVESO III was adopted in the EU and subsequently the member states had to adapt it in their legal environment. A research was carried among the SEVESO establishments in Slovakia and the results are published in this article. In spite of the alteration of the law it is possible to identify several changes which are to be done also in the next period. The article shows the results from the statistical research, the conclusions from meetings with the SEVESO establishments in Slovakia and consultations with the competent authority - the Ministry of Environment of the Slovak Republic. The results revealed a whole range of problems which were implemented in the law already in 2015. In spite of this fact some problems persist and it is necessary to solve them in the near future. Based on the meeting with experts from other EU countries and on the comparison of the results we can say that similar problems are found also in other member states.
\end{abstract}

\section{Introduction}

The industrial accidents as well as a whole range of other types of these events showed failures of the technology or the operators due to which a lot of people died or the effects caused them permanent consequences and losses of material values and environment which can be long lasting or even irreversible. Therefore the issue of preventing these events is in the first place and then the issue of implementing the preventive measures in the industrial environment. The EU tries to regulate this environment and to define the rules for the companies which are, from the point of view of concentrating the hazardous substance, the most dangerous ones, [1]. The directive SEVESO is one of them and it has been amended several times, for the time being the directive SEVESO III from 2013 is valid. [2].

The directive SEVESO III creates the basic framework dealing with prevention and preparedness for coping with the major industrial accidents with presence of the hazardous substances.

In connection with the changes of the EU regulations the EU member states were obliged to transpose the directive SEVESO III to their legal standards since $31^{\text {st }}$ May 2015. In Slovakia the transposition was realised by adopting the law No. 128/2015 Coll., from $6^{\text {th }}$ May 2015 about prevention of major industrial accidents. Even before the transposition, in 2013, in the framework of the research project MOPORI the Faculty of Security Engineering of the University of Žilina carried out a research whose results were included in the new legal regulation. Furthermore, the research acquired information through consultations with the company representatives regarding to the problem areas and possible solutions. [3]

\section{Statistical research in the SEVESO Establishments in 2013}

The basis of the statistical research was to investigate the knowledge and experience of the SEVESO establishments during preventing the major industrial accidents in the Slovak Republic.

The research addressed 81 SEVESO establishments from 26 lines of business that are in the Slovak territory. Out of 81 companies 44 returned the filled in questionnaires, the successfulness rate $54 \%$ (see the figure 1), however, some experts process the safety documentation for several enterprises simultaneously and therefore the successfulness rate was re-evaluated to $63 \%$ but always the individual questions from the total number of returned questionnaires - 44 - were assessed. [4]

This research was carried out before transposing the new directive SEVESO III to the legal environment of the Slovak Republic. The selected conclusions of the investigation were discussed also with the representatives of the Ministry of Environment of the Slovak Republic who expressed their opinions concerning this statistical research. 


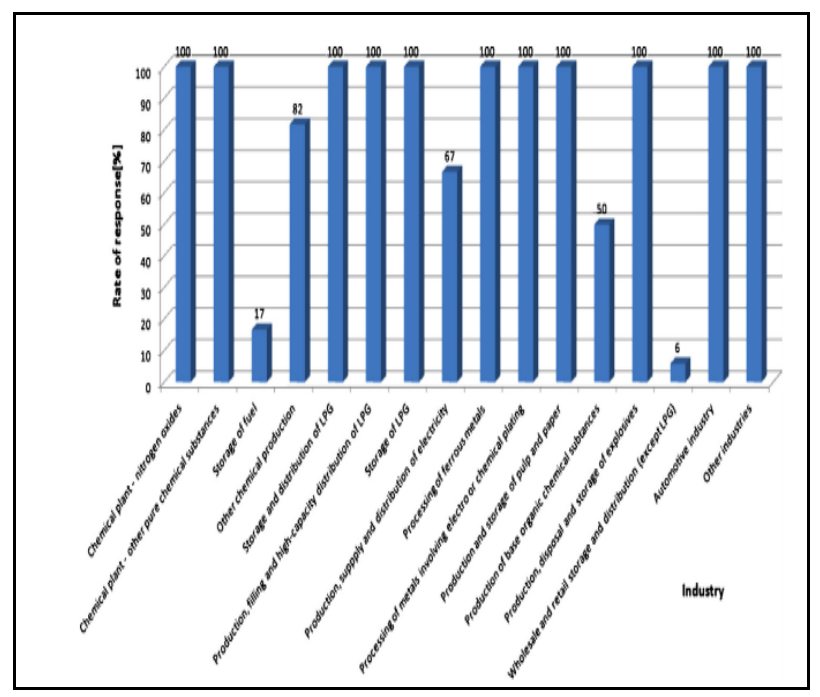

Fig. 1. Rate of return according the economic lines of business [\%]

Only relevant questions were chosen from the given research; however the material contained more answers to the selected questions.

\subsection{Results of the Statistical Research - Selected Questions}

This text brings only selected results of the research which are connected with the subject of this article.

\section{Administration and state administration}

In the framework of the old law the companies sent the safety documentation in the hard copy form (or they brought it to the Ministry of Environment) and it contained several documents rich in content. Therefore we asked a question concerning the form of sending the documents and our assumptions were right. Most frequently the SEVESO establishments suggested the electronic form for sending the documents. This possibility was supported by 31 SEVESO companies $(70 \%)$. 9 companies $(21 \%)$ preferred sending the documentation in the hard copy form and 4 enterprises (9\%) chose sending the documents on an electronic medium - CD-ROM, USB. [4]

It was found out it was necessary and at the same time desirable to consider the change of sending the documentation, which would simplify the work of not only the enterprises but also the specialised workplaces due to the volume this documentation represents, during the preparation of the new law by the Ministry of Environment. However, one question remained - the necessary technical outfit of the workplace that collects and keeps this documentation.

\section{Assessment and Management of the Risks}

One of the decisive criteria for assessing the qualification level of the specialists in the SEVESO establishments in the area of preventing major industrial accidents is their knowledge and capability to work with the methods of evaluating the major industrial accidents. The task of individual specialists was to choose (out of 16 best known methods for assessing the major industrial accidents) those ones they know and utilise or to complete some other methods.

The most frequently used methods the specialists in the SEVESO establishments used were - ETA (39 companies), FTA (38 companies) and the safety audit ( 26 companies). The figure 2 shows a thorough overview about the distribution of the methods for analysing the risks of the major industrial accidents according to the knowledge of the specialists for preventing the major industrial accidents.

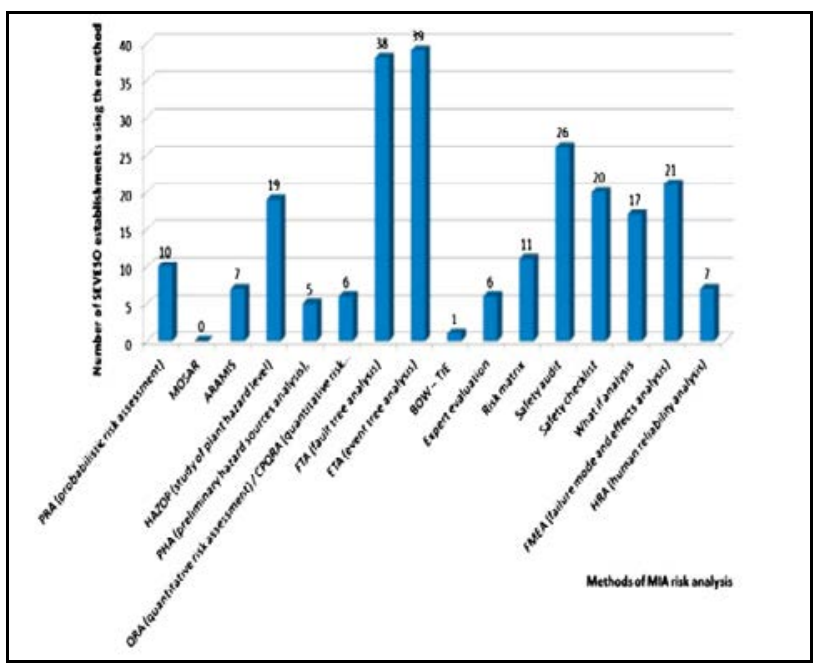

Fig.2.

The selection of the methods and techniques for the risk assessment depends not only on their availability but especially on the capability of the persons who will implement them. Currently the majority of the companies utilise the approach PRA (Probabilistic Risk Assessment). In the framework of the transposition of the directive SEVESO III to the legal environment of the EU states a space for creating a unified approach for the risk assessment opened and it enabled, especially the state administration, to compare the results of individual companies with each other and on the other hand it would simplify the operation during checking the official documentation. [5] However, no principal steps were made in this area and the unified methodology has not been implemented yet. [6]

Neither the EU directive nor the law about prevention of the major industrial accidents mention any software necessary for e.g. creating the scenarios, modelling the consequences and impact; however, it includes particular inputs for calculating the summaries of the impacts' 
seriousness. Currently there are several software products which can be utilised and they differ from each other especially by their availability and variability of the inputs and a different user environment.

All 44 SEVESO establishments answered the question concerning the usage of the software for assessing the risks of the major industrial accidents. The companies utilise especially the following software products: Excel, Aloha, TerEx, RiskSpectrum and Saphire. Out of the list in the questionnaire the companies use no other software products for assessing the major industrial accidents. They could also introduce other software products they use for assessing the risks of the major industrial accidents. They were as follows: ROZEX 2001, ALOFT-FT 3.10, IAEA-TEDDOC-7, Breze-Hass profesional, ATON. A predominant part of the companies said they were using EXCEL for the risk assessment (38 companies) and Aloha (37 companies). The overall division of the companies according to the information which software products they utilise for assessing the major industrial accidents - see the figure 3.

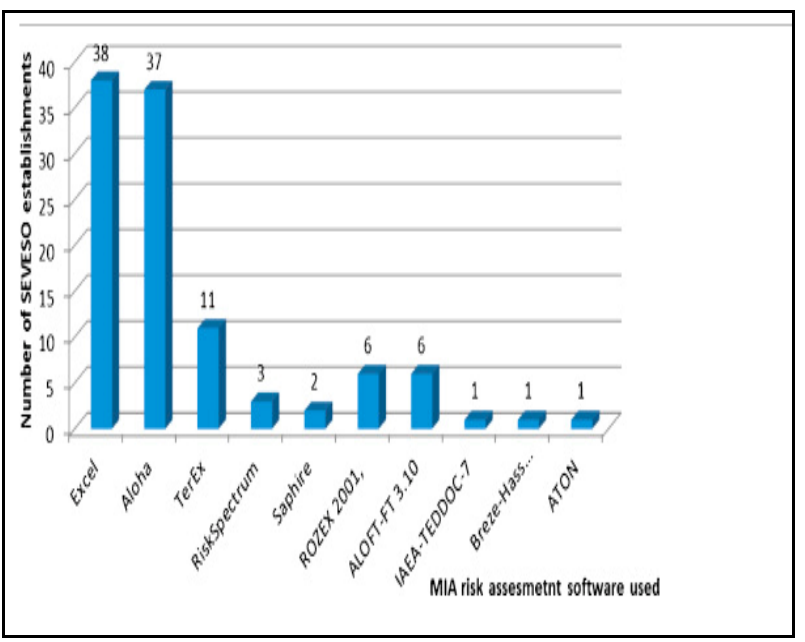

Fig. 3. The preference rate for individual software products for assessing the risks of the major industrial accidents in the SEVESO establishments.

The research results show a few conclusions which can be generalised. The companies utilise the programme MS Excel especially for creating FTA and ETA which are presented directly in the law as methods for making scenarios. Aloha is utilised for modelling the consequences of an undesirable event and the programme TerEx should not be in this list due to the fact it is determined for modelling the situation especially for the emergency units. The other software products are an individual matter of the joint-ventures with foreign participation and require a large financial investment (e.g. SAFETI).

\section{Research Results and Changes in the Law about Prevention of Major Industrial Accidents - Comparison}

In 2012 a new law about preventing the major industrial accidents began to be prepared. It was connected with a new classification of the hazardous substances and so a space for including other changes was created. Based on the findings in the framework of the statistical research a few areas which were then included in the new law about preventing the major industrial accidents were identified (see the Table 1).

Table 1. The identified changes in the framework of the research and the rate of fulfilment in the further period of the new law's validity $[7,8]$

\begin{tabular}{|c|c|}
\hline $\begin{array}{l}\text { Problem area identified } \\
\text { in the research }(2013)\end{array}$ & $\begin{array}{l}\text { Assessment of the } \\
\text { changes (2015) }\end{array}$ \\
\hline $\begin{array}{l}\text { Assessing the company } \\
\text { documentation without } \\
\text { professional capability } \\
\text { from the point of view of } \\
\text { the state administration }\end{array}$ & $\begin{array}{l}\text { Creating a council of } \\
\text { experts as an advisory } \\
\text { body of the Ministry of } \\
\text { Environment of the Slovak } \\
\text { Republic (specialists for } \\
\text { prevention of the major } \\
\text { industrial accidents), } \\
\text { checking the safety reports } \\
\text { with the aim of assessing } \\
\text { the risk. }\end{array}$ \\
\hline $\begin{array}{l}\text { Establishing the } \\
\text { emergency healthcare } \\
\text { service, the question of } \\
\text { firefighters in the premises } \\
\text { of the B category } \\
\text { enterprises. }\end{array}$ & $\begin{array}{l}\text { Currently in the valid law, } \\
\text { there remained only the } \\
\text { service of the accident } \\
\text { response for some B } \\
\text { category enterprises. }\end{array}$ \\
\hline $\begin{array}{l}\text { Frequency of inspections } \\
\text { in the SEVESO } \\
\text { establishments, } \\
\text { coordinated inspections. }\end{array}$ & $\begin{array}{l}\text { The inspections are } \\
\text { frequent and exactly } \\
\text { realised according to the } \\
\text { intervals in the directive } \\
\text { SEVESO III. The } \\
\text { coordinated inspections in } \\
\text { the B category enterprises } \\
\text { each } 12 \text { months (originally } \\
\text { even } 18 \text { ). }\end{array}$ \\
\hline $\begin{array}{l}\text { Selected hazardous } \\
\text { substances (problems with } \\
\text { generated substances, the } \\
\text { quantities for selected } \\
\text { hazardous substances). }\end{array}$ & $\begin{array}{l}\text { According to the new law, } \\
\text { the operator submits a list } \\
\text { of hazardous substances } \\
\text { present in the company or } \\
\text { an adapted safety report to } \\
\text { the district office in the } \\
\text { seat of the region and to } \\
\text { the Ministry of } \\
\text { Environment } \\
\text { electronically. }\end{array}$ \\
\hline $\begin{array}{l}\text { Adapting the terminology } \\
\text { and utilising the methods } \\
\text { for the risk assessment, a } \\
\text { unified approach. }\end{array}$ & $\begin{array}{l}\text { The terminology was } \\
\text { adapted to the actual trends } \\
\text { in the area of assessing the } \\
\text { risks and the existing as } \\
\text { well as the new terms were } \\
\text { completed and better }\end{array}$ \\
\hline
\end{tabular}




\begin{tabular}{|l|l|}
\hline & $\begin{array}{l}\text { explained, the usage of the } \\
\text { method remained on the } \\
\text { company's consideration } \\
\text { (ETA and FTA are } \\
\text { recommended). The } \\
\text { methodological manual } \\
\text { "Territorial Planning and } \\
\text { Permission Activities in } \\
\text { the Surrounding of } \\
\text { Existing and Designed } \\
\text { SEVESO Establishments " } \\
\text { contains a scheme of a } \\
\text { comprehensive model for } \\
\text { assessing the risks of the } \\
\text { industrial processes which } \\
\text { can be utilised result of } \\
\text { the MOPORI project) for } \\
\text { assessing the risks. }\end{array}$ \\
\hline $\begin{array}{l}\text { The manual "Identification } \\
\text { the domino effects and } \\
\text { communication with the } \\
\text { companies in the } \\
\text { surroundings. }\end{array}$ & $\begin{array}{l}\text { with Potential to Cause } \\
\text { Domino Effect" was } \\
\text { issued. }\end{array}$ \\
\hline $\begin{array}{l}\text { Failing to enable uniting } \\
\text { several companies in the } \\
\text { premises with the } \\
\text { possibility to work out } \\
\text { common documentation. }\end{array}$ & $\begin{array}{l}\text { The law does not allow } \\
\text { any association of the } \\
\text { companies in the industrial } \\
\text { parks; however, it } \\
\text { improves the conditions of } \\
\text { collaboration in the form } \\
\text { of determining the } \\
\text { neighbouring companies. }\end{array}$ \\
\hline $\begin{array}{l}\text { Failing to specify the } \\
\text { requirements of the } \\
\text { physical and object } \\
\text { protection for the } \\
\text { companies with hazardous } \\
\text { substances. }\end{array}$ & $\begin{array}{l}\text { There is no regulation in } \\
\text { this area; however, the } \\
\text { Czech Republic has this } \\
\text { regulation. }\end{array}$ \\
\hline
\end{tabular}

\section{Assessing the Law's Effectiveness and Identifying the Necessary Changes after Two Years of Its Validity}

The new law about preventing the major industrial accidents has been valid for two years. Several shortages which will have to be adapted through amendments to this law in the future have been identified during this time. The table 2 shows the basic problem areas and their assumed solutions.
Table 2.

Identified changes and problem areas in the new law about preventing the major industrial accidents

\begin{tabular}{|c|c|}
\hline $\begin{array}{c}\text { Problem area identified } \\
\text { in connection with the } \\
\text { new law }\end{array}$ & $\begin{array}{c}\text { Suggested solution in the } \\
\text { future }\end{array}$ \\
\hline $\begin{array}{l}\text { Changes in the framework } \\
\text { of REACH and CLP }\end{array}$ & $\begin{array}{l}\text { We consider extending the } \\
\text { list of hazardous } \\
\text { substances and mixtures by } \\
\text { new hazardous substances } \\
\text { (in the law about } \\
\text { preventing the major } \\
\text { industrial accidents). }\end{array}$ \\
\hline Safety documentation & $\begin{array}{l}\text { It is necessary to adapt } \\
\text { especially the requirements } \\
\text { on the safety report; it } \\
\text { should contain some } \\
\text { principal assessments } \\
\text { which were forgotten } \\
\text { during the amending } \\
\text { process. }\end{array}$ \\
\hline $\begin{array}{l}\text { Collaboration with the } \\
\text { competent bodies in the } \\
\text { area of preventing the } \\
\text { major industrial accidents }\end{array}$ & $\begin{array}{l}\text { It is necessary to } \\
\text { implement an integrated } \\
\text { approach in the area of } \\
\text { preventing the major } \\
\text { industrial accidents, we } \\
\text { expect an intensive } \\
\text { collaboration of the } \\
\text { competent units - the Civil } \\
\text { Defence; Protection of } \\
\text { Environment and Water; } \\
\text { Integrated Rescue System } \\
\text { and other rescue units in } \\
\text { the framework of preparing } \\
\text { and training the emergency } \\
\text { plans of the SEVESO } \\
\text { establishment. }\end{array}$ \\
\hline $\begin{array}{l}\text { Conception of a new law } \\
\text { and } \\
\text { regulations }\end{array}$ & $\begin{array}{l}\text { The new law and the } \\
\text { implementing regulation } \\
\text { are designed more freely } \\
\text { than the old law and its } \\
\text { implementation } \\
\text { regulations. The main } \\
\text { positive is that it enables } \\
\text { referring to other } \\
\text { documents which are } \\
\text { already prepared in the } \\
\text { company and this is a big } \\
\text { contribution in this area. }\end{array}$ \\
\hline $\begin{array}{l}\text { Errors in the safety } \\
\text { documentation from the } \\
\text { side of the enterprise }\end{array}$ & $\begin{array}{l}\text { The aforementioned more } \\
\text { general approach and } \\
\text { freedom were misused in } \\
\text { some companies and it led } \\
\text { to a situation when basic } \\
\text { information required in the } \\
\text { given safety documentation } \\
\text { was omitted. It would be } \\
\text { suitable to adapt selected } \\
\text { clauses in the law and to } \\
\text { complete the explanation }\end{array}$ \\
\hline
\end{tabular}




\begin{tabular}{|l|l|}
\hline & $\begin{array}{l}\text { comments to selected } \\
\text { clauses. }\end{array}$ \\
\hline Logistic warehouses & $\begin{array}{l}\text { Inspection of the selected } \\
\text { logistic warehouses with } \\
\text { hazardous substances due } \\
\text { to checking the amounts of } \\
\text { the hazardous substances } \\
\text { (they are not covered by } \\
\text { ADR, RID and ADN but } \\
\text { also by the law about } \\
\text { preventing major industrial } \\
\text { accidents), in general the } \\
\text { directive SEVESO III } \\
\text { defines it in a wrong way. }\end{array}$ \\
\hline
\end{tabular}

\section{Conclusion}

In this article we identified the basic problem areas in Slovakia whose selected conclusions are valid also for other EU member states. The directive SEVESO was amended not only on the basis of the particular industrial accidents but also due to the change of the chemical legislation during the recent period. In spite of this fact there develop problems which were shown in the previous tables.

The companies which are designated as under-threshold ones and do not fall under the law in spite of the fact they exceed the stated limit are a permanent problem. The solution of this problem is more of an ethical character because there is no power which would allow the responsible bodies to verify such facts in connection with potential ranking of these companies under the law. Also collaboration of the enterprises during defining the domino effect of the SEVESO establishment seems to be difficult also in spite of the fact a methodological manual for identifying the companies with a potential to cause the domino effect was worked out. The principal shortage is the unwillingness of the neighbouring companies to communicate with the SEVESO establishments and to give them information about the quantity of the hazardous substances which they need and to become a SEVESO company. The knowledgeability of the public is a very sensitive area; a lot of misunderstanding arises from the point of view of the enterprises and the public. [10] Last but not least, it is an insufficient analysis of the environmental impact of the major industrial accidents which are no priorities for a lot of companies.

\section{Aknowledgement}

„This work was supported by the Slovak Research and Development Agency under the contract No. APVV0043-10“"

\footnotetext{
"This article was created as a one of research project outcomes VEGA 1/0749/16 Risk assessment and treatment of industrial processes in relation with
}

integrated security and safety within lower tier establishments."

\section{References}

1. M. Hudakova et al.,. Analysis of the risks of small and medium-sized enterprises in the Zilina region. In: Communications : scientific letters of the University of Žilina. - ISSN 1335-4205. - Vol. 17, no. 1, s. 34-39. (2015)

2. SEVESO II Directive. [online]. [cited. 5.5.2012]. Available on: https://rod.eionet.europa.eu/instruments/588.

3. Major Accident hazard: The Seveso Directive Technological Disaster Risk Reduction. [online]. [cited. 7.3.2018]. Available on: http://ec.europa.eu/environment/seveso/index.htm.

4. K. Holla et al., Results of survey among SEVESO establishments in the Slovak Republic. In: Journal of chemical health \& safety. - ISSN 1871-5532. p. 9-17, - Vol. 23, no.2 (2016)

5. K. Sykorova et al., Lessons learned from environmental risk assessment within the framework of Seveso Directive in Czech Republic and Italy. In Journal of Loss Prevention in the Process Industries. (2017)

6. Ch. Delvosalle et al., Aramis project: $A$ comprehensive methodology for the identification of reference accident scenarios in process industries. Journal of Hazardous Materials. Volume 130, Issue 3, Pages 200-219. (2006)

7. K. Holla et. al, Complex Model for Risk Assessment. MOPORI project. University of Zilina in Zilina. (2014)

8. K. Holla et.al., Industrial Accidents Prevention. EDIS - UNIZA Žilina. ISBN 978-80-554-0786-9. (2014)

9. L.T. Ostrom, Risk Assessment: Tools, Techniques, and Their Applications. John Wiley and Sons, Inc., Publication. ISBN 978 - 0 - 470 - 89203 - 9. (2012)

10. M. Rausand., Risk Assessment: Theory, Methods, and Applications . Wiley publisher. ISBN: 978-0-47063764-7. (2011) 